\section{Contributors}

lain Bamforth is presently combing olives trees in Apulia. All little towns in southern Italy have cooperative presses. He takes his yield to them, and they bottle it. 'Top quality organic extra virgin - slightly bitter at first, but it mellows quickly and makes fabulous vinaigrette. At home we get through 15 litres every year.'

iainbamforth@orange.fr

Jonathan $\mathbf{R}$ Clowes worked as a relief GP 4 months/year on the island of Shapinsay, Orkney from 2005-2008, and is doing the same job on Westray, Orkney starting from 2010. He is currently in the middle of a 3-month full-time locum in the Falkland Islands. $\mathrm{He}$ is also a GP trainer (without trainee) and CSA and MAP examiner for the College.

jclowes@doctors.org.uk

Daniel Edgcumbe is a GP registrar in Histon, Cambs.

dr.edgcumbe@gmail.com

\section{Mike Fitzpatrick}

fitz@easynet.co.uk

The Brothers Glynn - Liam qualified from Trinity College, Dublin in 1995

and, after completing general practice

training in the Scottish highlands and

surviving some remote healthcare

postings to Guyana and Ecuador, he

returned to the West of Ireland where

he works as a GP principal in a single-

handed rural practice in the coastal

village of Ballyvaughan, Co Clare. He

is also a senior lecturer in general

practice at the National University of

Ireland, Galway.

liam.glynn@nuigalway.ie

Rachel Handscombe

rachel.handscombe@doctors.org.uk

Roger Jones, RMS McConaghey,

Denis Pereira Gray, Simon Barley,

Graham Buckley, Alastair Wright and

David Jewell have all edited the

various incarnations of the British

Journal of General Practice. A

collective noun for a group of medical

editors? Best suggestion wins $A$

History of the World in a Hundred

Objects by Neil McGregor, Director of

the British Museum (Allen Lane, 25

Oct 2010),

Roger Jones

journal@rcgp.org.uk

Denis Pereira Gray

denis.pereiragray@btinternet.com

Simon Barley

barleys@mac.com

Graham Buckley

egraham.buckley@virgin.net

Alastair F Wright

drafw@blueyonder.co.uk

David Jewell

david.jewell66@gmail.com

James Willis

jarwillis@gmail.com

\title{
Gated minds
}

I am astonished at how many people I speak to who have never heard of the burgeoning political phenomenon in the US which is known, either because Americans are without irony or because they have never heard of Mad Hatters, as the 'Tea Party'. But since the mid-term elections this new movement has become a power in the land, and therefore in the world, and it is high time we registered its existence and learned what it stands for, because you know what they say about things that happen in America ...

Quite a lot of my childhood happened in America, while my father was Atomic Energy Attaché at our embassy in Washington. I love the place and its traditions, its freedom, much of its culture. But recent trends there come close to filling me with despair. And the 'Tea Party' seems to wrap up those trends in one appalling package.

News reports after the elections have characterised this new movement as ultra-Conservative, angry at the economic situation, in favour of low taxes and small government. What I have not seen referred to is that a large proportion of its adherents are also creationists and global-warming deniers.

And you need a special kind of genius to sustain those beliefs in the face of the evidence. As you need a special kind of genius to explain why, in the 'Land of the Free' you use 'Liberal' (= free) as a term of abuse. Or why there is anything to be proud of about being illiberal (= selfish). Of course, if you can pull that trick people will like you for it. One explanation for the enduring appeal of the political right is that it enables people to feel good about their animal nature. Allowing them to sink back into their selfishness with grateful sighs and let civilisation go hang.

That explains the viciousness of the Tea Party opposition to President Obama's limited moves to civilise American health provision, which is the area perhaps best examined in the Back Pages of a British medical journal. The lies told about our $\mathrm{NHS}$, the 'death squads' and the rest of it, were too fatuous to arouse more than bemused indignation over here. But over there, the poison stuck. Because that is what happens with prejudice.

This is what the poisoners know: that when you are dealing with deeply ingrained prejudice, even the most devastating refutation can, paradoxically enough, actually strengthen the mistaken belief. Stephen Hawking, visiting the US at the height of the healthcare controversy, was held up as an example of someone who would be dead by now if he lived in Britain. His retort, that he did live in Britain and that he owed his life to the NHS, which sounded so much to us like a glorious killer blow, may actually have deepened the ignorance it should have enlightened.

Searching for a common link in the curious assortment of attitudes which makes up this political syndrome, I reject 'selfishness' because some of the individuals concerned are well-known to be the nicest people anyone could wish to meet. No, I come down to this extraordinary rejection of rationality. That is what is new and that is what is terrifying. Many people today really have turned their backs on the Enlightenment at just the time when the world is utterly dependent on science and reason for its daily functioning, let alone for its longterm survival.

This trend is part of an illiberal, irrational, anti-intellectual zeitgeist closely allied to the resurgence of fundamentalist religion in the Christian and Islamic worlds. It is, quite simply, dangerous. And as a friend at a lunch party told me today, it is stupid. It is terrifying that gated minds have moved into positions of power in the most important nation on earth. In the modern world ignorance is no excuse. Ignorance in the powerful is a disaster.

DOI: 10.3399/bjgp10X544249 